\title{
Territorial Issues on the East China Sea A Japanese Position
}

\author{
Shigeyoshi Ozaki ${ }^{*}$
}

\section{Introduction}

This article is intended to introduce the assertion of the Japanese government with regard to the territorial dispute over the Senkaku Islands, and to present an objective and reasoned examination to the problem in terms of international law. Before turning to the main part of the article, some basic points of international law shall be given as an introduction to the legal issues relevant to the dispute.

\section{A. Occupation as a Mode of Acquisition of State Territory}

The Japanese government has contended that the Senkaku Islands had been terra nullius (a territory without owner) until their incorporation into Japanese territory through the decision at the Japanese Cabinet meeting in 1895; that the Islands effectively became Japanese territory in terms of international law through their incorporation in 1895 and through the effective exercise of state functions over the Islands; and that the legal status of the Islands remains unchanged even after World War II. By contrast, both the Chinese and Taiwanese governments have contended that, historically speaking, the Senkaku Islands (Diao-yu Tai) have been their territory; and that Japan, while forcing the Qing government to cede Taiwan in accordance with the Treaty of Shimonoseki (1895), unilaterally incorporated those islands into her territory; and that the Islands should, like Taiwan, be returned to China. In comparing contentions raised by both parties, some critical issues are addressed as follows:

* Professor Emeritus of the University of Tsukuba. Address: 3-21, San'nomaru 1-chome, Mito City, Ibaragi Prefecture 310-0011, Japan. 
1. whether the Senkaku Islands were, in the light of international law as it stood in 1895, Chinese territory or terra nullius (a territory which was at the time not subject to the sovereignty of any state); and

2. whether Japan legitimately acquired the territorial sovereignty over the Senkaku Islands in accordance with the international law of the day, through the measures of territorial incorporation taken in 1895 and through Japan's effective control over them thereafter.

The Japanese government invokes the principle of 'occupation' as the legal ground for their contention. In general, international law recognizes the following modes of acquisition of territory as creating a title 1 to territorial sovereignty: occupation, prescription, cession, accretion and annexation (subjugation). Occupation is the appropriation of a territory by a state which is not at the time subject to the sovereignty of any state. ${ }^{2}$ Occupation is effected through taking possession of, and maintaining the exercise of state functions over, a territory in the name of, and for, the acquiring state. ${ }^{3}$ Occupation can only apply to a territory that is res nullius (the territory which is at the time not under the sovereignty of any state). Thus, occupation is in all cases lawful in origin, and the mere passage of time has no place in it. 4 Prescription, on the other hand, in international law means the acquisition of title by a continuous and undisturbed possession. Prescription is a concept which encapsulates situations where the original possession is unclear or disputed and unlawful possession. The possession must be continuous, undisturbed and demonstrating an act as a sovereign, while the former sovereign acquiesces to such possession throughout the period. Thus, prescription inherently requires a certain passage of time, although international law does not explicitly define how long the period should be. Today, prescription is normally recognized as one of the modes of acquisition of territorial sovereignty in international law. 5

However, as a matter of fact, it may often be uncertain whether the area in question has historically been a territory of a particular state, or terra nullius in international law in the actual territorial disputes. Such difficult cases have become apparent in territorial disputes, especially after the end of the 19th century when annexation or division of

1 "The primary meaning of 'title' is the vestitive facts which the law recognizes as creating a right." That is to say, every right (in a wide sense including privileges, powers and immunities) involves a title or source (i.e. certain facts) from which it is derived. Jennings made the following explanation. See R. Y. JENNINGS, THE AcQUISITION OF TERRITORY IN INTERNATIONAL LAW 4 (1963).

2 Id. at. 20.

3 ROBERT JENNINGS \& ARTHUR WATTS, OPPENHEIM's INTERNATIONAL LAW 688 (9th ed. 1992).

4 Jennings, supra note 1, at 23.

5 Id. at $20 \& 23$. 
colonies by western powers had almost come to an end.

Incidentally, both occupation and prescription have common requisites: (1) the will of a state to possess, and (2) effective possession. Bearing this in mind, the international jurisprudence in arbitral and judicial decisions of the 20th century does not intend to forcibly apply either occupation or prescription to each case, but rather applies indiscriminatingly a new title of "the actual, continuous and peaceful display of state functions in regard to the territory in dispute" 6 - the new concept of "effective occupation." 7 The concept of "effective occupation" itself had taken place in the 19th century and especially since the African Conference of Berlin in 1885. At that time, the requisite of occupation was the taking of physical possession of land and the exclusion of any other state by settlement or use of territory by other means. However, by the 20th century this theory had been decisively rejected by arbitral and judicial decisions (e.g., Island of Palmas case, 1928; Eastern Greenland case, 1931; Clipperton Island case, 1932; and Minquiers \& Ecrehos case, 1953). These cases make it clear that today the decisive test of the effectiveness of an occupation is whether the claimant has in fact displayed state functions in regard to the territory sufficiently to assure to other states "the minimum of protection of which international law is the guardian." 8 Thus, emphasis has clearly shifted from the taking of physical possession to the manifestation and exercise of the functions of government over the territory. The new concept of "effective occupation" might be said to blur the boundary between occupation and prescription. ${ }^{9}$ In the dispute over the jurisdiction over the Senkaku Islands, the Japanese government contends that its measures have been taken in accordance with the principle of occupation. Bearing in mind the evolution of the concept of 'occupation,' this article primarily attempts to examine whether the Senkaku Islands have historically been Chinese territory, or whether they were terra nullius in international law.

\section{B. Principle of Inter-temporal Law}

Modern international law came to be applied in the 16th to 17th centuries among the European states. International law was never known to Ming China or Ryukyu when Che-feng-shi Lu records 册封使録 (The Records of the Chinese Imperial envoys) were written by Chen Kan 陳㑆, Guo Ru-lin 郭汝霖 and others. Therefore, if China had at

\footnotetext{
Judge Max Huber, The Island of Palmas, 22 AM.J.INT'L L. 875-877 (1928).

C.H.M. Waldock, Disputed Sovereignty in the Falkland Islands Dependencies, 14 BRIT. Y. B. INT'L .L. $875-877$ (1948).

Huber, supra note 6 at 867, 876 .

9 Waldock, supra note 7, at 317-318. See also Kaname TaiJudo, RYodo KizoKU no KoKUSAI-HOU (TitLe to TerRITORY IN InTERNational LaW) 57-65 (1998). However, it is doubtful whether the Minquiers and Ecrehos case should be considered to be a territorial dispute to which occupation or prescription is relevant. See The Minquires and Ecrehos case (France v. U.K.), 1953 I.C.J. 80 (Judge Basdevant).
} 
that time considered the Senkaku Islands as its own territory and treated them as such, and if other states had not contended against such Chinese behavior, the Islands would have been recognized as Chinese territory. 10 In other words, if China had apparently expressed its will to possess those islands, if its sovereignty had truly extended to them, and if other states had acceded to this without calling it in question, then they would have been established as a Chinese territory without reference to any rule or of principle of contemporary international law of European origin, such as occupation. Actually, the overwhelming part that comprises Chinese territory today had been established as such through "ancient possession from time immemorial," 11 and its status has never been affected notwithstanding the acceptance of international law by the subsequent Chinese governments. As far as those uninhabited islands (like the Senkaku Islands that had once been too remote to approach from mainland China) are concerned, one can say that despite the fact that China's sovereignty had never actually covered the islands, if the will to possess them as its own territory had been manifestly displayed, and if no other states had disputed it, then the islands would be considered Chinese territory. In contrast, if the will to possess the islands had not been perceived explicitly due to their distance from the mainland, then it should be fair to say that the island's legal status would not have been established at that time; and that if they had been occupied by either Japan or China (or any other states) in accordance with the principle of occupation after both states had accepted international law, then the islands would have come under the jurisdiction of the occupying state at the very point of time. In that sense, unless the Chinese government had considered and treated the Senkaku Islands as its own territory, their status would not be different from that of the Ogasawara Islands, Minami-Daitou Island, and Minami-Tori Shima Island (Marcus Island), which are all said to have been acquired by Japan after the Meiji Restoration of 1868 in accordance with the principle of occupation. In the Minquiers and Ecrehos case (U.K. vs. France), the International Court of Justice ("ICJ") decided that, even if one of the parties had a primordial-feudalistic title dating back to the Middle Ages, that title was never applicable unless it was replaced by another valid title which later became necessary through the evolution of law. 12 The new valid title - as referred to by the Court - means title based on effective possession, which was required under the new concept of occupation. In the case of Japan and China, since their acceptance of modern international law in the 19th century had caused great changes in the international legal relationship around them, they should be encouraged to meet the requirement of the so-

\footnotetext{
Taijudo, supra note 9, at 142 (Chap. 3: Takeshima Funso/Takeshima Dispute).

Sakutaro Tachi, HeiJ Kokusal-hou (International LaW in Time of Peace) 356 (1932).

2 Basdevant, supra note 9, at 56.
} 
called inter-temporal law in that the ancient title should be replaced by the new valid one. ${ }^{13}$ It would follow that title to an uninhabited island lying between the two countries, the possessor of which not clearly established, must be newly established through such modes of acquisition of territory as the modern international law requires, once they had accepted it.

In this context, Japan, having newly accepted international law as a system of law since the mid-19th century, took measures to incorporate into its own territory several islands the possessor of which had not been established, in accordance with the principle of occupation (such as Ogasawara Islands, Minami-Daitou Island, and Minami-Tori Shima Island). The so-called territorial incorporation measures for the Senkaku Islands taken in 1895 were along this line.14

Hence, it should first be clearly ascertained as to whether China has tangibly regarded the Senkaku Islands as its own territory, before examining whether the practice of Japan, relative to the Islands in and after 1895, has satisfied the requirements of effective occupation as per principle of occupation. This point will be examined below in consideration of the historical facts.

\section{Have the Senkaku Islands Historically Belonged to China?}

\section{A. The State's Will to Possess}

(1) Can it be regarded as evidence of China's will to possess the Senkaku Islands that these islands are described in Chinese documents by Chinese names: Diao-yu $\mathrm{Yu}$ 釣魚 嶼 (魚釣島 in Japanese), Huang-wei Yu 黄尾嶼 (久場島 in Japanese), and Chi-wei Yu 赤 尾嶼 (久米赤島, later called 大正島)? The description of the Senkaku Islands in Japanese

13 The principle of inter-temporal law directly means that the effect of an act is to be determined by the law of the time when it was done, not by the law of the time when the claim is made. According to Judge Huber in the Island of Palmas case (1928), however, the principle contains two aspects. The first aspect is that "acts must be assessed against the law of the time they were performed." The second aspect is that "the existence of the right, in other words its continued manifestation, shall follow the conditions required by the evolution of law." Jennings, supra note 1, at 28-29) It is obvious that the decision of the Minquires and Ecrehos case focused on the second aspect of the inter-temporal law as described by Judge Huber.

14 As to the Ogasawara Islands, the Japanese Government notified her possession of the Islands to other countries in 1876, but did not receive any objection. This fact led to the establishment of the possession. As to Minami Daitoujima Island, the Japanese Government dispatched an expedition party in 1885, and took the incorporation measure in 1895 to render the Island to belong to the Okinawa Prefecture. Minami-Tori Shima Island, an uninhabited island, was discovered by a Japanese national (a private individual) in 1896, and the incorporation measure was taken in 1898 to render the Island to belong to the Ogasawara Branch Office of the Tokyo Prefecture. 
尖閣諸島, (Diao-yu Tai 釣魚台 in Chinese) first appeared in Chinese official records in Chen Kan 陳㑆's Shi Liu-qiu Lu records 使琉球録 (he visited Ryukyu in 1534 during the Ming Dynasty).

Beginning in 1372, the Che-feng-shi Missions 册封使 were dispatched from China when new king of Ryukyu acceded to the throne, in order to worship the deceased king and to formally recognize the new king by issuing imperial sanctions (Che-feng 册封). There were a total of 23 Che-feng-shi Missions from 1372 until 1879 (15 times during the Ming era, and 8 times during the Qing era). However, during that same time, Jin-gong Chuan - vessels of the tributary missions 進貢船 were sent from Ryukyu to China every year or once every two years (241 times in all). Also, official vessels such as Jie-feng Chuan 接貢船, Xie-en Chuan 謝恩船 and Qing-he-shi Chuan 慶賀使船 were dispatched 240 times from Ryukyu to China for various purposes. Clearly, the Ryukyuan vessels went to China much more often than the Chinese vessels went to Ryukyu, and thus the navigational courses between Ryukyu and China had been well known by the Ryukyuans. 15 For example, the below-mentioned party of Chen Kan completely trusted the Ryukyuan shipmen's pilotage on their courses. 16

During the Ming and Qing eras, sailboats dominated ocean navigation, and ocean routes were subject to the seasonal winds which varied from season to season. The same applies to the route between Ryukyu and China, in which great importance was attached to islands offshore or promontories, which served as landmarks to the vessels. 17 The Senkaku Islands, being located almost halfway along the route between Ryukyu and China, and having such peculiar and conspicuous forms, were ideal guides for navigation. It was for these reasons that the Senkaku Islands, a small uninhabited archipelago, which was difficult to anchor to and isolated by strong tidal currents, had been known to the Ryukuans and Chinese from relatively early times.18 It is true that the Senkaku Islands were described in the Che-feng-shi Lu records during the Ming and Qing eras, but this fact merely suggests that the Islands were known at that time as navigational guideposts for vessels sailing from China to Ryukyu.

(2) The descriptions of Diao-yu Yu 釣魚嶼, Huang-wei Yu 黃尾嶼 and Chi-wei Yu 赤尾嶼

15 Kanzo Akiyama, Nisshi Koshoshi-wa (History of Negotiation between Japan and China) 349 (1935). See also

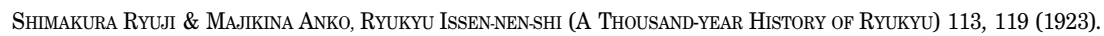

16 Kazuhiko Taira, 10(4) Chuugoku Shiseki ni Arawaretaru Senkaku (Tsuriuo) Shotou (Jou) (Senkaku (Diao-yu Tai) Islands as Appeared in the Chinese Historical Documents (Part 1)), Ajia-Afurika Shiryou Tsuhou [REFERENCE JouRNAL on Materials Concerning Asia and AFrica] 22 (1972).

17 Motoharu Fujita, Nisshi KoutsuU no Kenkyu - Chu-Kinsei-hen (A Study of Transportation between Japan and China - Medieval and Modern Periods) 236 (1938).

18 Id. at 232. 
are found in several Che-feng-shi Lu records (册封使録) after Chen Kan's record, any of which described the course from China to Ryukyu based on Chen Kan's record (visited Ryukyu in 1534).19 The descriptions state as follows:

\begin{abstract}
The envoys passed by the islands of Xiao Liu-qiu 小琉球 (present Ji-long Yu 鶏篭嶼), Ping-jia Shan 平佳山 (present Peng-jia Yu 彭佳嶼), Diao-yu Yu 釣魚嶼, Huang-mao Yu 黄毛嶼 (or Huang-wei Yu 黄尾嶼) and Chi-wei Yu 赤尾嶼 ; and “In the evening of [September] 11th," they "saw Gu-mi Shan Island (古米山) or Kume-jima Island 久米 島.” This is an island belonging to Ryukyu (Nai Shu Liu-qiu Zhe 乃属琉球者). The Ryukyuans aboard were so delighted to see this island as to shout 'hurrah' on the deck, knowing that they had almost reached their home.
\end{abstract}

It is evident from this quotation that Kume-jima island was the territory of Ryukyu (hence, the islands closer to China were not the territory of Ryukyu), but on the other hand, the quoted sentences never stated that they were the Chinese territory. Chinese historical documents, even relatively old ones, described with precision the territories and national boundaries. For example, Zhang Xue-li 張学礼 wrote in his record Shi Liuqiu Ji records 使琉球記 that "Shi Liu-qiu Bei-shan Yu Ri-ben Jiao-jie 是琉球北山與日本交 界 (This is an island in the northern part of Ryukyu, forming the boundary with Japan)"; and Xu Bao-guang 徐葆光 wrote in his Record Zhong-shan Chuan-xin Lu records 中山伝 聞録 that “Ba-zhong Shan - Ci Liu-qiu Ji-xi-nan Shu Jie Ye 八重山 此琉球極西南属界也 (Ba-zhong Shan or Yaeyama in Japanese is an island located on the southwestern skirts of Liu-qiu (or Ryukyu))." Besides, in consideration of Xu-xiu Tai-wan-fu Zhi 続修台湾府 志 (The Record of Taiwan Prefecture - a Sequel, published in 1763) and the other local records, the following phrasings are frequently used: Min Zhe Jiang Jie) (閩浙交界 (a boundary between Minjiang and Zhejiang), Yu Guang-dong Jiao-jie 與広東交界 (in the neighborhood of Gwangdong), and Xia Peng Fen Jie 澎厦分界 (a boundary between Xia-men and Peng-hu). Had the Chinese side thought that the point between Chi-wei $\mathrm{Yu}$ 赤尾嶼 and Gu-mi Shan; Kume-jima 久米島 islands formed the border between China and Ryukyu, then they would have used more direct language to such effect. However, according to Shu-yu Zhou-zi Lu (殊域周咨録 Records on Journeys to Foreign Territories) edited about 50 years later in 1582 by Yan Cong-jian (㛜従簡), a bureaucrat of the Ming Dynasty, it was not until the Chen Kan's party arrived at Kume-jima island that they "learned that the island was within the territory of Ryukyu (Wen Zhi Liu-qiu Jing-nei 問知琉球境內).” Therefore, the Chinese envoys, including Chen Kan, did not

19 The original text and its Japanese transcription/translation of Chen Kan 陳㑆's Shi Liu-qiu Lu Records 使琉球録 are included in Nahashi-shi (The History of Naha City), Vol. 3-1 (Original Text) and Vol. 3-2 (Translated Text). 
know that the Chinese territory ended at Chi-wei $\mathrm{Yu}$ 赤尾嶼 island. ${ }^{20}$ At that time, it was, indeed, an unmistakable fact for Chinese scholars like Chen Kan that neither Jilong $\mathrm{Yu}$ 鶏篭嶼 nor Peng-jia Yu 彭佳嶼, nor even the main island of Taiwan, had been Chinese territory. Accordingly, it is illogical to conclude that the Senkaku Islands, which were farther away, were Chinese territory.21 In addition, one should not fail to note that the expressions with regard to Kume-jima (久米島) island - that the island had been treated as "what belongs to Ryukyu (Nai Shu Liu-qiu Zhe 乃属琉球者)" and as “a guardian island which stands as a southwestern boundary of Ryukyu area (Liu-qiu Xinan-fang Jie Shang-zhen-shan 琉球西南方界上鎮山)”- had never appeared independently of the expressions of the Ryukyuan shipmen. This fact suggests that these expressions were used merely to represent how delighted the Ryukyuans sailors had been when they reached the territory of Ryukyu safely, and not in the sense of indicating a national boundary between China and Ryukyu. 22

As for the course from Ryukyu to China, we can find some similar expressions concerning the phrase of the "border of China (Zhong-guo Zhi Jie 中国之界). According to Xia Zi-yang 夏子陽' s record, on October 29, 1606:

In the early morning, we saw a ship in a far distance. Our shipmen were all excited to see it, saying that they have but a short distance left to their country, and that where the black water ends to face with the indigo water was unmistakably "the boundary of China," and immediately thereafter, These days, we have been so much anxious to reach our home island. This feeling is just the same as that of a starving man wanting to eat and drink, and of an infant adoring its darling mother 此数日舟人望山之切, 誠 不旁饑者之飲食嬰児慕慈母也.

Hence we can see that the Chinese aboard were delighted when they returned home safely. Likewise, its section on the course back to China, Li Ding-yuan (李鼎元) reads that:

On October 29, 1800, at 4 o'clock in the morning (戊寅 Wu-yin). Gentle wind blowing from the east. Dense fog. No change of the course. At 10 o'clock in the morning the fog cleared a little, and we saw 南杞山 (Nan-ji Shan island of Wenzhou 温州). The shipmen were all so delighted. 23

Shigeyoshi Ozaki, Senkaku-Shotou no Kokusaihoujo no Chii - Shu to shi te Rekishiteki Sokumen ni tsuite (The Legal Status of Senkaku Islands in International Law - Chiefly its Historical Aspect), 18 TsuKuBa HoSeI (TsuKUBA UNIVERSITY REVIEW of LaW AND PoLITICS) 187-190 (1995).

21 Taira, supra, note 16 at 15.

22 Id. at. 16. See also Kazutaka Kishiba, 20 Senkaku Shotou no Enkaku to Kizoku Mondai (The History and the Problem of the Belonging of Senkaku Islands), KAIJ-SHI KENKYUU (JOURNAL OF THE HisTORY OF MARITIME AFFAIRS) 55-59 (April 1973).

23 Shi Liu-qiu Ji 使琉球記, Vol. 6. 
In this description, too, one finds the expression “the boundary of China 中国之界” used to refer to the spot where Mt. Nan-ji Shan of Wen Zhou had first come into their view, which made them so delighted. The Chinese shipmen were sure that the island was inhabited by Chinese and was included in Chinese territory. Thus, it is at this spot where the shipmen were so delighted to celebrate their safe voyage home and such phrasings were applied as Gu-mi Shan Island, i.e., what belongs to Ryukyu (Gu-mi Shan, Nai Shu Liu-qiu Zhe 古米山, 乃属琉球者) and certainly the boundary of China (Bi Shi Zhong-guo Zhi Jie 必是中国之界). Therefore, reading both passages together, one can say that the islands between Gu-mi Shan island (belonging to Ryukyu) and Mt. Nan-ji Shan of Wen Zhou (of China) had been uninhabited islands, and had thereby been the territory of neither country. ${ }^{24}$ (This is also important in the context of the title to the Senkaku Islands).

(3) The next record by Guo Ru-lin 郭汝霖 stated that "Chi-wei Yu is an island forming the border with the Ryukyu area (Chi-wei Zhe Jie Liu-qiu Di-fang Shan Ye 赤嶼者界琉球 地方山也).” 25 However, this just demonstrates that Chi-wei Yu, or Sekibi-sho 赤尾嶼 island stood as a boundary of the Ryukyu area, i.e., it just reconfirmed the findings of Chen Kan. The Zhong-shan Chuan-xin Lu 中山伝信録 was written by the third Che-fengshi envoy dispatched by the Qing Dynasty, Xu Bao-guang 徐葆光 visiting Ryukyu in 1719. Xu Bao-guang and Hai Bao 海宝, the Vice Envoy and Envoy respectively, also has a description of Kume-jima island as "Liu-qiu Xi-nan-fang Jie Shang-zhen-shan 琉球西 南方界上鎭山 (a guardian island which stands as a southwestern boundary of Ryukyu)." As far as the title to the Senkaku Islands is concerned, this description was, after all, the same as those made by Chen Kan and Guo Ru-lin, with no new additional discoveries. While all of these quotations commonly admitted that islands far away from Ryukyu, such as Kume-jima island, were considered within territory of the Kingdom of Ryukyu (and that thereby the Senkaku Islands had not been included in the Ryukyuan territory), none of them lead to the conclusion that the Senkaku Islands were part of Chinese territory. 26

Some Che-feng-shi Lu records called the sea area 'Gou 溝 (or Jiao 郊)' around Chiwei $\mathrm{Yu}$, or Sekibi-sho 赤尾嶼, an area that "divides China from the outside" or as "the border between Ryukyu and Minhai of China." At sea vessels crossed a belt-shaped torrent of the Kuroshio Current, and the color of the sea water changed from blue (shallow sea) to deep black (deep sea). Hence, shipmen called the area Hei-shui Gou 黒

24 Ozaki, supra note 20, at 239-240.

25 Chong-ke Shi Liu-qiu Lu 重刻使琉球録 The Record of the Mission to the Ryukyu Islands (revised) (visiting Ryukyu in 1561).

26 Ozaki, supra note 20, at 190-194. 
水溝 or simply 'Gou' (deriving from its cavity- and belt-shaped form), which was so feared for its treacherous navigation that they conducted the ceremony of "Guo Gou, Ji Hai 過溝·祭海 (prayers to the sea god for the safe passage across the 'Gou 溝' spot).” However, the exact identification of the 'Gou' spot was quite difficult, and there was no pattern of descriptions in this regard among each one of the records. Thereafter, as navigation security improved, use of the 'Gou' ceremony ceased and the term was not found later in the records. In sum, the term "Gou 溝 or Jiao 郊” referred to the change of seawater or currents of some waterways, but not to the national borders. 27

The same applies to the description of “what divides China from outside(中外之界)." The terms did not imply any particular territorial or political meaning as the borders of China with another country, but was surely used as a figurative expression of the rather obscure "borders between two waters", that is, between Chinese water (as Minhai 閩海) and the ocean or the Ryukyuan waters, which expression being based on the assumption that the 'Gou' 溝 really existed. Some records that treated the sea area between the Kume-jima and Sekibi-sho islands as "what divides China from the outside" or "the boundary with Min Hai" never expressed anything as to the state to which the Sekibi-sho 赤尾嶼 and Koubi-sho 黄尾嶼 islands belong to in relation to the explanation of the two phrases in question. Accordingly, we can safely conclude that the descriptions in Chinese records of 'Gou 溝' or 'Jiao 郊”" and "what divides China from outside 中外之界” regarding the waters near Chi-wei Yu or Sekibi-sho 赤尾嶼 island could never be the ground for determining that the Senkaku Islands had been Chinese territory. 28

(4) Yan Hai Shan Sha Tu 沿海山沙図 (A Map of the Coastal Islands of China) forms the first volume of the book, Chou-hai Tu-bian 籌海図編 (A Picture Book of Chou-hai Area) (1563), a historical document relating to coastal defense in the Ming era, in which a map described the Senkaku Islands as islands just on the coast of 羅源 (Luo-yuan) and Ningde (寧徳) Prefectures of the Fujian Province, though the islands were described as being far off the coast. Does this fact demonstrate that the Senkaku Islands were regarded as Chinese territory on the coast of Fujian? The book included "Fu Jian Yan Hai Zong Tu 福 建沿海総困 (A Map of the Maritime Topography on the Coast of Fujian)” in its 4th volume, in which "Peng-hu Yu 澎湖嶼” was referred to, whereas Taiwan 台湾, Keelung $\mathrm{Yu}$ 基隆嶼 (located in the northeast of Taiwan), Peng-jia Yu (彭佳嶼), and the Senkaku Islands were not. This description better coincided with the situation of that time in the area. In reading such government records of local history, such as Luo-yuan Xuan Zhi

27 Id. at $196-208$.

28 Id. 
羅源県志 The Record of Luo-yuan County (written in the Ming period, 1614) and Ningde Xuan Zhi (寧徳県志 The Record of Ning-de County in the Qing period, 1718), it is acknowledged that the Senkaku Islands had not been included in the administrative zone of these prefectures of the Fujian Province. Also, a map "Fu Jian Hai Fang Quan Tu 福建海防全図 (A Complete Map of Fujian for Coastal Defense) that was placed in the first volume of the government record, Zhong Zuan Fu Jian Tong Zhi 重纂福建通志,29 did not mention any sign of the Senkaku Islands at all. The influence of Ming China did not cover the northern part of Taiwan Keelung 基隆 area, islands in the northeast of Taiwan such as Peng-jia Yu 彭佳嶼, Hua-ping Yu 花瓶嶼, Mian-hua Yu 棉花嶼, or the Senkaku Islands. Furthermore, Ming China did not have any will to possess them. ${ }^{30}$ Hence, the conclusion to be drawn from the fact that these islands were mentioned in the Yan Hai Shan Sha Tu 沿海山沙図 (A map included in Chou-hai Tu-bian 籌海図編) must be, at the very best, that they were located exactly in the route taken by the Japanese pirates (Wokou 倭寇), and that thereby the whole area was a zone to be closely watched for the defense of mainland China. 31

(5) Last, had the Senkaku Islands ever been included in the administrative zone of China in the Ming and Qing ages? In the regional historical documents of Fujian Province in the Ming and Qing ages and those of Taiwan in the Qing period, one cannot find any mention of the fact that the Senkaku Islands had belonged to Fujian Province or Taiwan. Fu Jian Tong Zhi (福建通志 A Complete Record of Fujian) which was edited by the Qing government in 1684 clearly demonstrated that the Senkaku Islands were not included in the administrative zone of Fujian Province at that time. ${ }^{32}$ In 1684, during the Qing period, Taiwan was incorporated into the Chinese territory and the Taiwan Prefecture was established. The Taiwan Prefectural Government published a variety of records of Taiwan Province starting with the first 台湾府志 Tai Wan Fu Zhi (1686). According to any of these historical books, the northern end of Taiwan was Ji-long Yu 鶏篭嶼 (today's Keelung Yu 基隆嶼), and neither the Senkaku Islands nor any other

29 A Complete Record of Fujian (re-edited) (1838).

30 According to the official history of Ming China 'Ming Shi' 明史, Taiwan was categorized as 東蕃 (Dong Fan) (The Barbarian's Land in the East) (mentioned in a volume of 外国列伝 Wai Guo Lie Chuan (The Biography of Foreign Countries). Ji-long Shan 鶏箁山, located in the northern part of Taiwan (today's Keelung 基隆), was also mentioned in that particular volume.)

31 Ozaki, supra note 20 , at 220-226.

32 There was no description of the Senkaku Islands in the maps “Fu Jian Quan Sheng Zong Tu 福建全省総㘠 [A Complete Map of All Over Fujian Province]” or in “Tai Wan Fu San Xuan Tu 台湾府二県図 (A map of the Three Counties of Taiwan Prefecture)," both maps being included in the first volume of the Provincial Record. Nor was there any mention of the Senkaku Islands in the bodies of the maps or in the Zhong-zuan Fu-jian Tong Zhi 重纂福建通志 (A Complete Record of Fujian (re-edited)). 
islands closer to Taiwan, e.g., Hua-ping Yu 花瓶嶼, Mian-hua Yu 綿花嶼, Peng-jia Yu 彭 佳嶼 etc., were included in the administrative zone of the Taiwan Prefecture.33

\section{B. Names of the Islands}

(1) Chinese names such as Diao-yu Yu 釣魚嶼, Huang-wei Yu 黄尾嶼, and "Chi-wei Yu 赤尾嶼 are supposed to be the expressions in Chinese characters representing the Ryukyuan names of these islands, which Chen Kan 陳㑆 knew by asking questions to the Ryukyuan shipmen aboard with him. This supposition naturally fits situation at the time of the shipping lanes between China and Ryukyu. It is clear that there is some relevance between the island names recorded in Chinese documents and those names that had long been handed down for generations of Ryukyuans. ${ }^{34}$ As to Diao-yu Yu 釣 魚嶼 and Huang-wei $Y u$ 黄尾嶼, there are some native island names that have long been used in Okinawa from ancient times. The names consist of two types: Yukun (or Yokon)-Kuba Shima used in the mainland Okinawa, and ligun-Kuba Shima used in Yaeyama 八重山 area.35 This 'Yukun' is almost certainly derived from "Iyu," a dialect word of mainland Okinawa that means fish. The islands were so named as to refer to 'a very fishable island.' The word 'Iigun' of the Yaeyama area is supposed to be derived from the shape of an island that is sharply edged like a harpoon to be used to catch fish by piking. 36

As a matter of fact, both words are related to fish or fishing. Judging from the descriptions that, as the Che-feng-shi Lu Records 册封使録 often stated, big fish had appeared in the sea area around the Senkaku Islands, one can assume that the area was a fruitful fishing area (due to the Kuroshio current) and that fishermen in the Yaeyama area sailed to the Senkaku Islands for this very reason. This is documented in the Narrative of the Voyage of H. M. S. Samarang, an English battleship whose captain was Sir Edward Belcher, who, for the first time in history, made a survey of the Senkaku Islands in June 1845.37 In this Narrative of the Voyage are recorded the following facts:

33 For details, see id. at 226-228.

34 Ozaki, supra note 20, at 208-220.

35 It is said that these island names have been known only to some people of the Yaeyama area who had been engaged in trading with Southeast Asian and European countries that began at around the end of the 15th century and in sailing to the mainland Okinawa. Kiyoshi Makino, Senkaku Rettou (Iigun-Kuba-jima) Shou-shi (A Historical Sketch on the Senkaku Islands (Iigun-Kuba-jima)), 56 KIKAN OKINAWA (QUARTERLY OKINAWA) 65 (1971).

36 Kiyoshi Makino, Shin Yaeyama ReKishi (The History of Yaeyama Island) 32 (1972).

37 Edward Belcher, Narrative of the Voyage of H.M.S. Samarang, During the Years 1843-1846, $315-317$ (1848). To this book was attached a "Navigational Chart of the North China Sea and the Sea around Japan (including the new discoveries made by the Samarang)," in which the Senkaku Islands had been marked in the correct location by the names of 'Hoa-pin-Su,' 'Ti-a-usu,' and Raleigh Rock. 
- the islands were so familiar to the Yaeyama (八重山) fishermen that they (especially those from Ishigaki-jima) (石垣島 An island of Yaeyama Islands) have had enough knowledge of the course;

- there was a trace in Huang-wei Yu 黄尾嶼 which showed some drifters had just lived there - namely, fishermen from Ishigaki-jima island seem to have often appeared around these islands in question for fishing or have happened to be there adrift; and

- the people of Ishigaki-jima island called these islands by names (possibly "IigunKuba Shima”) different from those described in navigational charts. 38

It is thus clear that there is some relevance between the Ryukyuan names of ligun (or Yukun) and Kuba Shima and the Chinese names of Diao-yu Yu 釣魚嶼 and Huang-wei $\mathrm{Yu}$ 黄尾嶼 - where the former have been handed down orally from generation to generation, while the latter have been explicitly recorded in Chinese documents. Taking into context the shipping traffic between China and Ryukyu at that time, one can assume that the Ryukyuan shipmen, did not understand Chinese characters told these Ryukyuan names to the Chinese aboard the ship. In this way the names were recorded as Diao-yu Yu 釣魚嶼, Huang-wei Yu 黄尾嶼 and the like. It is, indeed, not finally determined since this cannot be certified with documents of direct relevance. However, the fact that the islands in question had been recorded as Chinese names does not help to form much evidence of the then Chinese people's recognition of those islands as their own territory, in light of the shipping traffic situation between China and Ryukyu. The terms 'Kuba Shima,' a Ryukyuan name, derive from the abundance of "kuba" (a Ryukyuan name of a palm tree that grows in clusters all over the island). In this context, the names of Huang-wei Yu 黄尾嶼, Huang-mao Yu 黄毛嶼 and Huang-ma Yu 黄麻嶼 all correspond to "Kuba Shima" in their substantial meaning. The name Chi-wei Yu 赤 尾嶼 or Chi $\mathrm{Yu}$ 赤嶼 corresponds to the fact that the island was traditionally called Kumi-aka Shima deriving from the appearance of the island having abundant red clay in the soil, and from its closeness to Kume-jima island in comparison with Diao-yu Yu 釣魚嶼 and Huang-wei Yu 黄尾嶼.39

(2) There is one more thing to be pointed out that reveals some important implication from Che-feng-shi Lu Records 册封使録 in relation to the present problem of the names of islands. Zhong-shan Chuan-xin Lu 中山伝信録 (written by Xu Bao-guang 徐葆光) showed in a chapter regarding the course of Che-feng-shi envoys 册封使 back to Fuzhou 福州 of China, the route from Naha port to Fuzhou via the Gu-mi Shan 古米山 and Gu-

38 Id.

39 Ozaki, supra note 20, at 211, 218. 
ba-shen-ma Shan 姑巴甚麻山 islands and Nanqi-shan 南杞山 of Wenzhou (温州), China. The name Gu-ba-shen-ma 姑巴甚麻山 Shan is apparently a Ryukyuan expression of Kuba-jima 久場島 rewritten in Chinese characters, where Kuba-jima is a Ryukyuan expression of Huang-wei Yu 黄尾嶼, an island of the Senkaku Islands. This description should not be overlooked, since it spelled out the fact that as early as 1719 the Ryukuan name Kuba Shima had already been used (in the form of 'Gu-ba-shen-ma Shan') in the Chinese official historical document with regard to an island of the Senkaku Islands.

Some similarities are seen in the other records. Namely, a record ' $\mathrm{Xu}$ Liu-qiu-guo Zhi-lue 続琉球国志略' written by Zhao Xin 趙新, the last Che-feng-shi envoy 册封使 who went to Ryukyu in 1866, described their courses taken in 1838 and 1866 as follows:

On May 4th, 1838, we launched from Wuhu-men 五虎門 out to the broad ocean, and May 5, at 2 o'clock in the afternoon, we saw Ban-jia Shan (牛架山) in the south. On May 6th, at 2 o'clock in the afternoon, we directed our course toward Diao-yu Shan (釣魚山), and at 4 o'clock in the afternoon, toward Kuba-jima island 久場島. At the dawn of May 7th, toward Jiu-mi-chi Dao 久米赤島 island (the then Ryukyuan name of Chi-wei Yu 赤尾嶼). At the dawn of May 8th, toward Gu-mi Dao (姑米島) island.

On June 9th [1866], we cruised on the broad ocean. On June 10th at 2 o'clock in the afternoon, we passed by Ban-jia Shan 牛架山. On 11th at 6 o'clock in the evening, we passed by Diao-yu Shan (釣魚山), and at 8 o'clock in the evening, we passed by Kuba-jima 久場島 island. On the 12th at 2 o'clock in the afternoon, we passed by Jiumi-chi Dao 久米赤島 island. On the 15th at 8 o'clock in the morning, Gu-mi Shan 姑 米山 island came into view.

It is worth noting that in these two descriptions, both Huang-wei Yu 黄尾嶼 and Chi-wei Yu 赤尾嶼 were written in Ryukyuan names only as Kuba-jima 久場島 and Kume-Aka-jiima 久米赤島. Hence, these two official records of the Che-feng-shi envoys (册封使) dispatched by the Qing Government had used the Ryukyuan names to refer to the Senkaku Islands and that these Ryukyuan names were written together with other Ryukyuan names like Gu-mi Shan 姑米山, Ma-chi Shan 馬歯山, and Na-ba Gang 那覇港 without making any distinction from other Chinese names. This is important fact to prove that these two islands were not recognized by China as its own territory, and that China had no intention or will to incorporate them into its own territory 40 


\section{Principle of Discovery}

As mentioned above, before Chen Kan 陳㑆's visit to Ryukyu, the Senkaku Islands had already been familiar, and their names having been established, among the Ryukyuan shipmen. On the other hand, Chen Kan was the official envoy sent by the Ming Dynasty and he referred to these islands together with their names in the official record. Hence, it may seem that he was a discoverer as defined in the principle of discovery. 41 It must be noted that the descriptions of the Senkaku Islands in Chen Kan's and the other succeeding Che-feng-shi Lu Records 册封使録 did not show the Chinese government's will to possess these islands. At the time, these islands were considered important just because they were useful as landmarks for navigation, and the names of the islands were probably given for that purpose. Moreover, it was not acknowledged at the time that the islands had been generally regarded as Chinese territory, or that the successive Che-feng-shi $\mathrm{Lu}$ records showed that the envoys desired the islands to be Chinese territory. Indeed the envoys had interest in the islands but merely as landmarks for navigation. The successive envoys only saw the islands from afar in their cruising vessels. They never approached the islands and explored them with the will to possess them, neither landed on islands nor proclaimed that those islands were Chinese territory, nor made any symbolic act for annexation. Furthermore, there was no description in the Che-feng-shi Lu records, which formed an official report after the envoys return to China, to the effect that they recommended the possession of those islands. None of recent Chinese governments have confirmed such a recommendation, or proclaimed the will to possess the islands. In sum, there is no description in the Chinese historical documents that indicated the will to possess the Senkaku Islands. Therefore, it is clear that the Chinese contention based on these documents does not correspond to "discovery" as defined in the principle of discovery. 42

As discussed above, it is true that the Chinese documents (especially, the Che-feng-shi $L u$ 册封使録 records) and documents on coastal defense during the Ming period) referred to the Senkaku Islands. However, they were so mentioned as a guide for navigation purposes used by shipmen and Japanese pirates (Wo-kou 倭寇). No

41 The principle of discovery that allows the one who first discovered the land to acquire it, was started in Europe in the 15th to 16th century (Age of Geographical Discovery) as a principle for land acquisition. It is thus impossible under the principle of inter-temporal law to apply this principle to the China-Ryukyu relationship in the Ming period, but such usage of the principle of discovery will be briefly discussed below.

42 As to the principle of discovery, see the following articles: Sakutarou Tachi, Mushu no Tousho no Sensen no Houri to Senrei (Some Jurisprudence and Precedential Cases Concerning the Occupation of Terra Nullius) 32-38, KoKUSAIHOU Gaikou Zasshi (The Journal of International LaW \& Diplomacy) 3-4; Kaname Taijudou, 61-62 Kokusaihou jou no Sensen ni tsuite (Concerning Occupation in International Law), Hougaku Ronsou (Kyoto UnIVERSITY Law REviEw) 55-56; Waldock, supra note 7, at 322-324. 
evidence can be discerned from these documents that China intended to possess the Senkaku Islands. Thus it turns out that the Senkaku Islands had not been regarded by the Ming and Qing China as Chinese territory, nor had they been treated as such. It is clear that the Chinese dynasties did not have any interest in such uninhabitable and remote coastal islands and that China did not have the will to possess them. Accordingly, one cannot but conclude that historically speaking, the Senkaku Islands were not the territory of China. It is also clear that these islands were not the territory of Ryukyu, either. Therefore, the conclusion of the present section is that the Sankaku Islands had been terra nullius in terms of international law until 1895 when the Japanese government incorporated them in its territory based on a formal decision at the Cabinet meeting.

\section{Did Japan Acquire the Territorial Sovereignty over the Senkaku Islands in an Effective Way in Accordance with International Law?}

(1) A state can acquire a terra nullius (a territory not belonging to any state in international law) by way of occupation. It is evident that international law applied to Japan after the Meiji Restoration and to China after the middle of the 19th century. Hence, both countries could have acquired by way of occupation the Senkaku Islands. The Japanese government contends that the Cabinet meeting in January 1895, which incorporated the Senkaku Islands into the Okinawa Prefecture and gave Japan effective control over these islands, were in accord with the requirements of occupation under international law, and that the Senkaku Islands legally became Japanese territory. This section will examine whether this contention is justified under international law.

In international law, the State should effectively occupy the land with its will to possess in order to render the possession effective. This requirement of effective occupation was established in the latter half of the 19th century. Prior to this requirement, emphasis was placed on the actual occupation of the land itself, such as use, settlement and colonization of the land by a state's nationals. It was later required that local authorities should be established on the land in question to maintain order and to take responsibility for administration in order to have an effective occupation. 43 This new requirement was intended to assure within the territory in question "the

43 Article 35 of the General Act of the Conference of Berlin respecting the Congo, signed on February 26, 1885-86. See Taijudo, supra note 9 , at 57 . 
minimum of protection of which international law is the guardian" 44 against other states or the nationals of other states, and thus, it was required that a certain degree of sovereignty was actually exercised in the land in question. In order to meet this requirement, it would be necessary to establish a local administrative agency and to maintain police and military forces. In the case of an uninhabited island, however, establishment of an administrative agency and placement of police and military forces are actually not necessitated, nor is it plausible to establish or place such agencies or forces in an uninhabitable island. 45

In the 20th century, further development was observed in the context of the requirement relative to effective occupation. Namely, the requirement remains the same that the state sovereignty of the occupying state should be exercised over the land in question, but the recent international jurisprudence took this requirement as "the continuous and peaceful display of territorial sovereignty." 46 In other words, when a state exercises or displays its sovereignty over a land in a continuous and peaceful manner, the fact is taken as constituting the ground for acquisition of the land in question by the state. This is similar to the concept of prescription as mentioned at Section 1.

In this context, being peaceful means that the land in question is not a land occupied by another state, and that the occupation has not been disputed by competing states. 47 Being continuous means that a state's sovereignty is continuously exercised or displayed on the land; however, this criterion is relative in the sense that it depends on each case with respect to the time span and the length of any interruptions permitted. Namely, it depends on whether the land is inhabited or not, and on whether there are other states' competing acts of sovereignty or not. Lastly, the exercise or display of state sovereignty should be done in an effective manner. Exercise of local administrative power, jurisdiction, legislative power and so on is particularly important as a display of state sovereignty. The extent of the effectiveness depends on the shape of the land in question, existence or non-existence of inhabitants, population density, existence or nonexistence of other states' competing acts of sovereignty etc. 48 With these factors in mind, it will now be discussed whether a series of measures taken by the Japanese government over the Senkaku Islands met the requirements of occupation.

\footnotetext{
44 Permanent Court of Arbitration, Arbitral Award in the case of Sovereignty over the Island of Palmas (or Miangas) (1928) (The Award is contained in the form of Appendix in Jennings, supra note 1, at 88-126).

45 Waldock, supra note 7, at 317. See Kisaburo Yokota, KoKUsai Hou (International LaW II) 91 (Yuhikaku Press, 1958). Tachi, supra note 11 , at $16-17$.

46 Huber, supra note 6.

47 Waldock, supra note 7, at 335.

$48 \quad$ Id. at 336.
} 
(2) The Japanese government, since 1885, through the Okinawa Prefectural authorities and otherwise, has repeatedly conducted field surveys, and took the Cabinet decision on January 14, 1895 to the effect that a marking pole would be placed, whereby the Senkaku Islands were officially incorporated into Okinawa Prefecture as a part of the Japanese territory. In this way, the Japanese will to possess the Islands was explicitly expressed (without any competition with the other states' will to possess them). ${ }^{49}$ It seems that on the site, Mr. Tatsushiro Koga, authorized for exploitation of the Islands, established a marking wood pile, where a workshop and a house were built and a national flag was raised.50 In addition, as will be discussed below, there are ample facts that indicate the exercise of sovereignty by the Japanese government over the Senkaku Islands. 51 Hence, it can be concluded that the Japanese will to possess the Islands was clearly demonstrated.

What significance can be attached to the fact that the Japanese government took the domestic measure of incorporation of the Senkaku Islands into its territory in the form of a Cabinet decision? As a requirement of occupation, no certain domestic procedures for territorial incorporation are required. In terms of international law, the requirement of occupation would be fully satisfied if there is a clear expression (whether explicitly or implicitly) of the will of the occupying state to possess the territory and if the other states are in a position to know such an expression and yet to fail to protest. In this context, what could be said of the fact that no specific notification to foreign countries was made in the process of incorporation of the Senkaku Islands? It is true that notification to foreign countries clarifies the will of the state to possess the territory in question. 52 Generally speaking, such notification is preferable because it allows for confirmation of whether other states' contention over the land in question exists and because it expedites clarification of the scope of the area relating to the occupation. In terms of the positive international law, however, notification to foreign countries cannot be said to be a requirement of occupation. The opinion of most scholars does not agree that such notification to foreign countries is a requirement of occupation. The arbitration awards in the Palmas Island case (1928) and in the Clipperton Island case (1931) decided that no notification to the foreign countries is required. When Japan occupied the Ogasawara Islands, Minami-tori Shima island, Iojima island etc., no notification was made to the foreign countries with regard to the occupation itself. Accordingly, the lack

49 As to the process up to the Cabinet Decision in January 1895 (territory incorporation measure), see SHIGEYOSHI Ozaki, Senkaku-Shotou no Kizoku nit suite (II) (The Territorial Sovereignty over the Senkaku Islands (II)), Reference, No. 261, 39-49 (1972).

50 Id. at 50-51. See also photos contained in Noritaka Tsuneto, Nantou no Fugen (Rich Sources of Southern Islands) (1909).

51 Ozaki, supra note 20 , at 51-56.

52 ShigeYoshi Ozaki, Senkaku-Shotou no Kizoku nit sutTe (IV) (The TerRitorial Sovereignty over the Senkaku IsLand IV), Reference No. 263 (Dec. 1972), at. 168-69. See also Tachi, supra note 11, at 12. 
of notification to foreign countries does not affect the legal effect of the incorporation measures. 53

(3) No other countries expressed any objection to the territorial incorporation by Japan of the Senkaku Islands and the development thereof. Until 1970, no other countries including China lodged any protest against the Japanese possession of the Senkaku Islands. The exercise of state sovereignty of Japan over the Islands has been conducted in a peaceful manner. In contrast, there is another opinion that as of 1895, China was not in a position to raise any objection to the issue of the Senkaku Islands after its defeat in the war with Japan. However, any protest in accordance with international law can be made regardless of victory or defeat in a war. Had China recognized the Islands as her own territory during the war, during the negotiations for the Sino-Japanese Peace Treaty and even afterwards, China should naturally have taken any measures including protest against the Japanese action which they did not.54

Incidentally, Japan had determined its will to possess the Senkaku Islands already in 1885, but the actual incorporation measures were taken ten years later in January 1895 when the victory of Japan in the Sino-Japanese war was nearly secured. Some argue that the Senkaku Islands were taken by force under the pretext of the victory in the war; as a matter of fact, the situation was as follows. The incorporation measures were not taken in 1885 due to the conservative approach adopted by the Minister of Foreign Affairs, which prevailed in his negotiations with the Minister of Internal Affairs in October 1885. During the negotiations, the Minister of Internal Affairs, referring to the report of the Governor of Okinawa Prefecture, advised that from the legal perspective there was no issue in placing the Senkaku Islands under the jurisdiction of Okinawa Prefecture and in putting up a national pole.55 On the other hand, the Foreign Minister viewed the situation from a purely political lens. According to the Foreign Minister, the matter related only to small islands, which were close to the national border with the Qing Dynasty China,56 and which were named by the Qing Dynasty. Additionally, there were some rumors alleged in the newspapers of the Qing Dynasty China that the Japanese government occupied the islands of the Qing Dynasty adjacent to Taiwan. In light of these considerations, the Foreign Minister remarked that it would better to delay

\footnotetext{
Ozaki, supra note 20 , at $168-69$.

54 Id. at 169.

55 The Internal Minister quite rightly acknowledged that the islands seemed to correspond to those originally described in the Che-feng-shi $\mathrm{Lu}$ records 册封使録. However, this only suggested that vessels from the Qing Dynasty took their courses toward the islands for the purpose of navigation. Therefore, no evidence existed that proved that the islands were the territory of the Qing Dynasty, and that the records only evidenced the fact that the names of the islands were merely different in China and in Ryukyu.

56 It should be noted that he did not treat them as within the territory of the Qing Dynasty.
} 
incorporation for another day.

At that time, the issue of which state Ryukyu belonged to was not established and remained as a pending matter between the two countries. Japan steadily advanced its case for ownership over Ryuku, and thus it was not in the best interest of Japan to antagonize the Qing Dynasty over the relatively small islands adjacent to Ryukyu. Thereafter, the official suggestions advanced by the Okinawa Prefectural Governor in 1890 and 1893 were rejected, and it thus seems that the Japanese government had already determined to wage war on the Qing Dynasty. The delay in incorporation of the Senkaku Islands may have some political significance but it is of no legal significance, because China could have taken measures for incorporation by occupation anytime during the period of inaction on the part of Japan. 57

(4) Japan took possession of the Senkaku Islands by an act of occupation, which, from a legal viewpoint, was totally different from the measure of possession when Taiwan ceded to Japan pursuant to the Sino-Japanese Peace Treaty (the so-called Treaty of Shimonoseki signed on April 17, 1895), although both measures occurred during the same period. This means that the Senkaku Islands were not handed over from China to Japan as "islands appertaining or belonging to the said island of Formosa" as defined in Article 2 of the Treaty of Shimonoseki.

By the time of cession of Taiwan to Japan, the administrative area of Taiwan governed by the Qing Dynasty did not include Peng-jia Yu 彭佳嶼, Mian-hua Yu 綿花 嶼, and Hua-ping Yu 花瓶嶼, all three islands being located northeast of Taiwan. Hence, no one considered the Senkaku Islands, located even farther away from Taiwan, to be "islands appertaining or belonging to the said island of Formosa." Without exception, all maps and marine charts of Taiwan issued in Japan until 1895 described the scope of Taiwan as far as Peng-jia Yu 彭佳嶼. Accordingly, it was common knowledge shared by Japan and the Qing Dynasty that "islands appertaining or belonging to the said island of Formosa officially recognized in marine charts and maps and so on" at the time when Taiwan was handed over to Japan in June 1895 did not include the Senkaku Islands. 58

(5) Exercise of sovereignty by the Japanese government over the Senkaku Islands before and after 1895 sufficiently meets the test of "the peaceful and continuous expression of state sovereignty" as required by today's international law. In short, the exploitation and management of the Islands by Mr. Tatsushiro Koga during which there were a

57 Ozaki, supra note 52, at 43-45, with reference to 18 NIPPON GaIKo MonJo (Documents OF JAPANESE DiPLOMACY), at 534-535 \& 573-575.

58 Ozaki, supra note 52, at 50-59. 
variety of facts showing the exercise of the sovereignty of Japan, were authorized and encouraged by the Japanese government, whereby the Japanese sovereignty effectively covered the Senkaku Islands. There is other evidence of an actual and continuous display of sovereignty that sufficiently show Japan's exercise thereof in view of the fact that the Senkaku Islands were uninhabitable and isolated islands: namely, exercise of administrative power such as description of the islands in the national land ledger, setting of lot numbers, rent and sale of national land as such, collection of taxes, a land survey, description of the islands in official governmental documents, description of the islands in maps and marine charts published by the Japanese government, dispatch of government clerks, academic survey, and police activities such as rescuing the shipwrecked. Slowdown in the use of land by Mr. Koga in the Showa era rendered the exercise of the sovereignty of Japan less active than before; however, the display of sovereignty never ceased during the era, nor were there any challenges by any competing sovereign acts of other states. 59

(6) After World War II, the United States occupied and governed Okinawa, taking over the area of the Okinawa Prefecture as defined before the war, which included the Senkaku Islands. This is clearly seen in a variety of legislative measures of the United States in Okinawa.60 Furthermore, the United States and the Government of the Ryukyu Islands exercised their sovereignty over the Senkaku Islands consistently, though not always actively. Hence, it was confirmed from the practice of the United States, a third party after World War II, that the Senkaku Islands, like Okinawa, were under the jurisdiction of Japan before World War II. In addition, no countries including China had raised any objections until 1970 with regard to the treatment of the Senkaku Islands as part of Okinawa and to the transfer thereof to the United States. This fact must surely have great evidential value relative to the possession of the Senkaku Islands by Japan.61

(7) If China had really regarded the Senkaku Islands as an integral part of its own territory, then China could and should have rightly made protests with respect to the Japanese possession of the Islands in accordance with international law. The fact that no

59 Id. at 50-56.

60 Id. at 56-60. For example, the United States established the Government of the Ryukyu Islands in 1952 in effectuation of the Treaty of Peace with Japan. The legal ground of the establishment, "Provisions of the Government of the Ryukyu Islands (Ordinance No. 68 of the United States Civil Administration of the Ryukyu Islands)," describes the political and geographical jurisdiction of the Government of the Ryukyu Islands by longitude and latitude, according to which the Senkaku Islands is clearly included in the jurisdiction. Provisions of the Government of the Ryukyu Islands (issued on February 29, 1952, took effect on April 1, 1952), art. 1. For the text thereof, see Ozaki, supra note 52 , at 57 .

61 Ozaki, supra note 52, at 170-171. 
legal countermeasures whatsoever were taken with regard to the Japanese possession of the Islands would necessarily constitute acquiescence, which is a requirement of prescription. China should have made protests and taken some other legal measures at the time either when Japan incorporated the Islands into Okinawa Prefecture, Taiwan and Okinawa (including the Senkaku Islands) were separated from Japan after World War II, or when the Treaty of Peace with Japan or the Sino-Japanese Peace Treaty were concluded. Indeed, China could have made protests in this regard at any time. However, China never displayed any reaction to the Japanese incorporation of the Senkaku Islands for 75 years up until 1970. As such, it is apparent that China (both Beijing and Taipei) evidently denied its claim to the Senkaku Islands throughout the period. 62

The Taiwan Sheng Tong Zhi Gao 台湾省通志稿, edited by the Taiwan Ministry Documents Committee 台湾省文献委員会, shows that Ping-jia Yu 彭佳嶼 is the northernmost of the Taiwan Province.63 The same applies to the "Map of the Taiwan Province 台湾省図,” an appendix to the Taiwan Sheng Tong Zhi Gao, which shows that the territory of Taiwan extends up to the eastern end of Mian-hua Yu (棉花嶼) (基隆市 棉花嶼東端 東経一二二度六分二五秒) and to the northern end of Peng-jia Yu 彭佳嶼 (基隆市彭佳嶼北端 北緯 25 度三七分五三秒).64 The Taiwan-sheng Di-fang Zi-zhi-zhi-yao (台湾省地方自治誌要) 65 and the Chung-hua min-kuo nien-chien 中華民國年鑑66 both describe the territory of Taiwan as extending up to the eastern end of Mian-hua Yu 棉花 嶼 and to the northern end of Peng-jia Yu (彭佳嶼).67 World Maps Vol. 1 East Asian Countries 世界地図集第一册 東亜諸国 published by the Defense Laboratory 国防研究院 of Taiwan and the China Geological Institute 中国地学研究所68 explicitly treated Diaoyu Dao “魚釣島” and other islands as Japanese territory in the name of Senkaku Islands 尖閣群島. A government textbook of the Republic of China, Guo min Zhong xue Di li ke Jiao $k e$ shu 国民中学地理科教科書 69 also clearly indicated the Senkaku Islands as part of the Ryukyu Islands with dotted lines in the Liu-Qiu Qun-Dao Di-xing Tu 琉球群島地形図 of the textbook.70

The same applies to the attitude of the People's Republic of China. For example, the

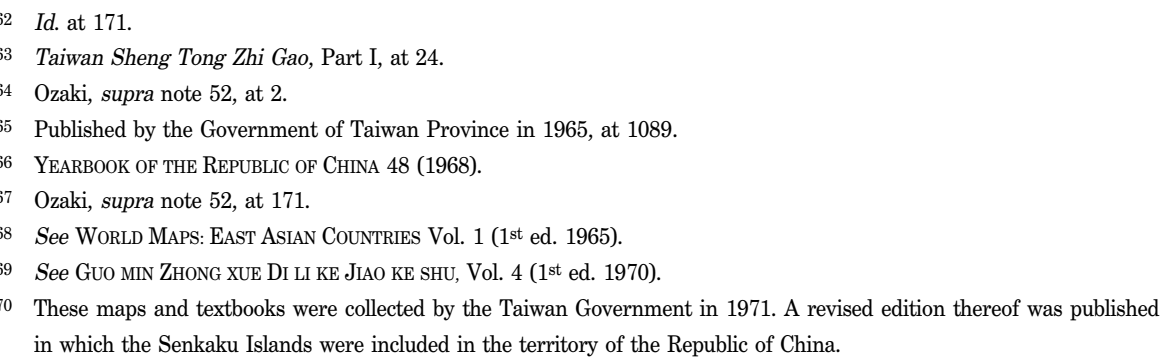


Ren Min Ri Bao 人民日報 Newspaper dated January 8, 1953, printed an editorial titled "Struggle for Protesting [the] American Occupation of the People of the Ryukyu Islands," which clearly described the Senkaku Islands as included in the Ryukyu Islands:

The Ryukyu Islands lie in the sea area between the northeast of Taiwan and southwest of Kyushu, Japan, including seven groups of islands comprised of the entire Senkaku Islands, Sakishima Islands, Daitou Islands, Okinawa Islands, Oshima Islands, Tokara Islands and Osumi Islands, each having many large and small islands in the proximity thereof [Emphasis added].琉球群島佈散在我国台湾東北和 日本九州西南之間的海面上, 包括尖閣諸島, 先島諸島,大東諸島, 沖縄諸島, 大島諸島， 吐噶喇諸島, 大隅諸島等七組島嶼, 每組都有許多大小島嶼)

A map entitled, Ryukyu Islands (琉球群島),71 describes the Senkaku Islands by the names of Senkaku Islands 尖閣諸島, Uotsuri-jima Island 魚釣島 and so on, which are clearly indicated to be included in the Ryukyu Islands. The Map of the People's Republic of China 中華人民共和国地図72 still included in the December 1971 designation of the Senkaku Islands by the names Diao-yu Dao 釣魚島 and “Chi-wei Yu 赤尾嶼” to be included in the area of Ryukyu. Taiwan dili (台湾地理) written by Beijing, Commercial Press 吳壮達 states that the territory of Taiwan extends up to Mian-hua Yu 棉花嶼 in the eastern end and up to Ping-jia Yu 彭佳嶼 in the northern end: Islands are distributed in the entire area ... the northernmost boarder of the Taiwan is the northeast of Ping-jia Yu, and advancing about $56 \mathrm{~km}$, one will face the Senkaku Islands located inside the Ryukyu Islands [Emphasis added]. 全区島嶼的分布，....... 最北是本島東北的彭佳嶼，地距瑞芳鎮的鼻頭 角約五六公里, 与琉球群島內側的尖閣諸島遙対73

The explanations above readily lead to the conclusion of the present section. First, a series of exercises and display of state sovereignty over the Senkaku Islands by the Japanese Government since January 1895 fully met the requirements under current international law for occupation, and therefore, Japan acquired title to the Senkaku Islands in an effective manner. Second, no change in the status of the islands has been made since the end of World War II. It is apparent from a variety of legislative measures taken in Okinawa by the United States that the area of Okinawa, separated from Japan and placed under the administration of the United States, includes the Senkaku Islands. Finally, China never raised any objection to the Japanese incorporation of the Senkaku

\footnotetext{
71 This map formed part of the World Maps 世界地龱集 (published by the Editorial Department of the) (SinoMaps Press 地図出版社, 1958).

72 The first edition was published in June 1957 and the sixth edition was published in December 1971 by the Sino Maps Press 地図出版社 and issued by China International Book Trading Corporation 中国国際書店.

73 Ozaki, supra note 52 , at 172 .
} 
Islands for 75 years up until 1970 when the territorial dispute arose. Furthermore, both Beijing and Taipei acknowledged the fact actively through their state policies. ${ }^{74}$

\section{Conclusion}

As discussed above, acknowledgement of the fact that the Senkaku Islands belong to Japan would lead to almost no problems in terms of international law. Japan should continue to firmly maintain actual effective control over the Senkaku Islands while amicably claiming its own legitimate rights to the islands with China. In doing so, Japan must consistently persuade the other parties using all colorable legal arguments. The best solution to the territorial dispute would be for a legitimate and sensible settlement through negotiations between the parties, keeping in mind the historical facts and legal arguments made throughout this paper. No one can predict how the dispute over the title to the Senkaku Islands will develop in the future, but the present writer hopes that both Japan and China will discuss the matter in the spirit of mutual cooperation and concession and work toward a reasonable solution.

74 Needless to say, any acts of either of the parties to a territorial dispute subsequent to its breakout do not affect the legal evaluation of the dispute under international law (the so-called principle of "critical date"). Accordingly, China's enactment of the "Law of the Territorial Sea and the Contiguous Zone" in 1992 to incorporate the Senkaku Islands into her territory does not have any relevance whatsoever in international law to the issue of the title to the Islands. 